\title{
Microbial solvent formation revisited by comparative genome analysis
}

\author{
Anja Poehlein', José David Montoya Solano², Stefanie K. Flitsch², Preben Krabben³, Klaus Winzer4, \\ Sharon J. Reid ${ }^{5}$, David T. Jones ${ }^{6}$, Edward Green ${ }^{7}$, Nigel P. Minton ${ }^{4}$, Rolf Daniel ${ }^{1}$ and Peter Dürre ${ }^{2^{*}}$ (I)
}

\begin{abstract}
Background: Microbial formation of acetone, isopropanol, and butanol is largely restricted to bacteria belonging to the genus Clostridium. This ability has been industrially exploited over the last 100 years. The solvents are important feedstocks for the chemical and biofuel industry. However, biological synthesis suffers from high substrate costs and competition from chemical synthesis supported by the low price of crude oil. To render the biotechnological production economically viable again, improvements in microbial and fermentation performance are necessary. However, no comprehensive comparisons of respective species and strains used and their specific abilities exist today.

Results: The genomes of a total 30 saccharolytic Clostridium strains, representative of the species Clostridium acetobutylicum, C. aurantibutyricum, C. beijerinckii, C. diolis, C. felsineum, C. pasteurianum, C. puniceum, C. roseum, C. saccharobutylicum, and C. saccharoperbutylacetonicum, have been determined; 10 of them completely, and compared to 14 published genomes of other solvent-forming clostridia. Two major groups could be differentiated and several misclassified species were detected.
\end{abstract}

Conclusions: Our findings represent a comprehensive study of phylogeny and taxonomy of clostridial solvent producers that highlights differences in energy conservation mechanisms and substrate utilization between strains, and allow for the first time a direct comparison of sequentially selected industrial strains at the genetic level. Detailed data mining is now possible, supporting the identification of new engineering targets for improved solvent production.

Keywords: Acetone, Butanol, Clostridium acetobutylicum, C. beijerinckii, C. saccharobutylicum, C. saccharoperbutylacetonicum, Phylogeny, Solvents

\section{Background}

Acetone and butanol are important solvents that are used to manufacture adhesives, cosmetics, lacquers, paints, plastics, pharmaceuticals, and polymers in combined chemical markets worth more than $\$ 6$ billion [1]. Today, most of this market demand is met with solvents derived from oil. During the first part of the last century, the production of these solvents via the acetonebutanol-ethanol (ABE) fermentation process served as the major source of industrial solvents. Solvent-producing clostridia became a focus of interest during the early

\footnotetext{
*Correspondence: peter.duerre@uni-ulm.de

${ }^{2}$ Institut für Mikrobiologie und Biotechnologie, Universität UIm,

Albert-Einstein-Allee 11,89081 Ulm, Germany

Full list of author information is available at the end of the article
}

1900s, due to their potential for the commercial production of solvents. Initial studies were centered on production of butanol for the manufacture of synthetic rubber. With the advent of WW1, emphasis rapidly shifted to the production of acetone that was needed in large volumes for the production of munitions. In 1915, Charles (later Chaim) Weizmann from the University of Manchester was granted his famous patent for the production of acetone and butanol using an anaerobic bacterium [2]. This organism was later named Clostridium acetobutylicum [3]. During WW1, the production of acetone on industrial scale was undertaken in the UK, France, Canada, and the USA and played a vital role in munitions' production for the Allies. Weizmann's contribution was recognized by the British Government and played a part in the Balfour declaration in 1917, providing the initial nucleus 
for founding the state of Israel in 1948, with Weizmann becoming the countries first president $[4,5]$.

After the war, the need for large volumes of acetone fell away and butanol production became the main commercial focus. The Weizmann process and patent were acquired by the Commercial Solvent Corporation (CSC) in the US and the company remained the sole producer of solvents until the patent expired in 1930. During the 1930s, three other US chemical companies established their own, independent, industrial $\mathrm{ABE}$ processes and $\mathrm{ABE}$ plants were also established in Cuba, Puerto Rico, and South Africa. Beginning in the 1920s, Japan also embarked a major program for the production of butanol as an aviation fuel supplement. This government program eventuated in the building of numerous ABE plants in Japan and Taiwan prior to and during WW2 [6]. The Japanese program was initially based on a derivative of the Weizmann strain before the isolation and development of Japanese solvent-producing strains. None of these early strains appear to have survived, but some successful industrial strains designated C. saccharoperbutylacetonicum, from the post war period, were lodged with international strain collections.

During the 1930s, the expanding sugar industry resulted in a world-wide glut in molasses and an overproduction of sugar cane juice. This resulted in the fermentation industry switching to this abundant, much cheaper substrate. The $C$. acetobutylicum strain patented by Weizmann and its various derivatives that were developed to produce solvent from corn and other starch-based substrates proved to be unsuitable for use on molasses and similar sugar-based substrates. From the 1930s, all four of the US companies utilized molasses as the substrate for the $\mathrm{ABE}$ fermentation. This involved each of the US companies in the isolation, selection, and development of their own closely guarded, in house, solvent-producing strains for use on molasses. Some of these strains were also able to reduce acetone further to isopropanol. Many of these were patented under a multiplicity of different names [5]. Unfortunately, the only examples of this new generation of industrial saccharolytic strains to have survived are those developed and patented by CSC along with some later strains developed by McCoy, who had worked as a consultant for CSC. These included strains utilized in the Puerto Rico process. As a joint venture, CSC established a new molasses-based ABE plant in the UK in 1935 utilizing the new generation of CSC industrial stains. The National Chemical Products (NCP) plant established in South Africa originally utilized a French derivative of the Weizmann strain using corn as the substrate. During WW2, the NCP plant in South Africa was converted to using molasses as the substrate.
The NCP industrial strain collection is the most complete collection of $\mathrm{ABE}$ bacteria and based on strains originally supplied by CSC, from the US, during 1944 and 1945 with further strains supplied by Commercial Solvents-Great Britain (CS-GB) in 1951. The main CSC industrial strains were patented under the names of $C$. saccharo-acetobutylicum, C. granulobacter acetobutylicum, and C. saccharo-butyl-acetonicum-liquifaciens [7]. A strain of C. saccharo-acetobutylicum is now known as C. beijerinckii NRRL B-591/NCIMB 8052. The later C. granulobacter acetobutylicum strains were transferred to NCP and are now classified as NCP C. beijerinckii strains. The C. saccharo-butyl-acetonicum-liquifaciens strains were also transferred to NCP and are now classified as C. saccharobutylicum.

The ABE fermentation flourished in the US, the UK, and Japan until the 1950s, when solvents manufactured from cheap crude oil made the ABE fermentation process increasingly uneconomic. The ABE plant in the UK ceased operation in 1959. The ABE plants in Japan closed in the early 1960s. The last ABE plant in the US operated by Publicker Industries ceased operation in 1977. South Africa operated an ABE plant until 1983, while China continued to maintain several plants and, in 2006, established several new ones. However, these soon became uneconomic due to decreasing oil price and most were closed by 2009 .

More recently, Green Biologics has applied modern microbiology and advanced engineering to the conventional ABE fermentation process. The company has constructed a renewable chemicals facility in Little Falls, Minnesota by retrofitting a 21 million gallon-per year ethanol plant with their advanced Clostridium fermentation technology to produce bio-based butanol and acetone for chemical applications. Production is expected to ramp up to full capacity during 2017.

Better understanding and intimate knowledge of genome sequence from industrial strains, used commercially over 70 years, will support efforts to engineer and develop superior microbes for solvent production. There is a need to develop robust and highly productive strains that can utilize low cost and sustainable renewable feedstocks and make a significant contribution toward a more economically viable and environmentally friendly fermentation route for commodity chemical and biofuel production.

\section{Results}

\section{Phylogeny and taxonomy}

Until recently, only the sequences of some C. acetobutylicum, C. beijerinckii strains, and C. diolis were publicly available, but many other species such as $C$. aurantibutyricum, C. felsineum, C. pasteurianum, C. puniceum, 
C. roseum, C. saccharobutylicum, and C. saccharoperbutylacetonicum are able to perform $\mathrm{ABE}$ fermentation. Genomes from all these species, including all type strains, were sequenced. Genomes of C. saccharobutylicum strains BAS/B3/SW/136, NCP 195, NCP 200, NCP 258, DSM 13864, of C. saccharoperbutylacetonicum strains N1-4 (HMT), N1-504, of C. pasteurianum DSM 525, and of C. beijerinckii BAS/B3/I/124 and 59B were closed, all other genomes are draft form (Table 1). The historical development of the sequenced industrial strains is depicted in Fig. 1. Genome sizes vary between $4.099 \mathrm{Mb}$ (C. acetobutylicum NCCB 24020) and $6.666 \mathrm{Mb}$ [C. saccharoperbutylacetonicum N1-4 (HMT)]. The latter is the largest genome within the solventogenic clostridia. We found the lowest number of genes (around 4000) in the genomes of the C. acetobutylicum species and the highest number (5937) in C. saccharoperbutylacetonicum N1-4 (HMT). To correlate metabolic potential with strain phylogeny, we compared our newly derived genome sequences with those that are publicly available. A whole genome comparison based on protein-encoding genes revealed a core genome shared by all 44 strains of 547 orthologous groups (OGs) and a pan genome of 31,060 OGs (Fig. 2). There was a broad range of genome-specific OGs (singletons) varying between 11 and 737, which is, with three exceptions, smaller than the core genome of all 44 strains studied. Three genomes, namely C. pasteurianum BC1, Clostridium sp. Maddingley MBC34-24, and C. puniceum DSM 2619 encoded 1155, 1212 and 1455 singletons, respectively, which is $2-3$ times higher than the core genome of all analyzed strains.

The phylogeny of the strains was analyzed by multilocus sequence analysis (MLSA) based on the detected core genome (Fig. 3). The phylogenic tree yielded two main clades (I and II) with several subclades. The first comprises a $C$. acetobutylicum, a $C$. roseum/C. aurantibutyricum/C. felsineum, and a C. pasteurianum subclade, whereas $C$. pasteurianum $\mathrm{BC} 1$ branches outside the last-mentioned subclade. The second main clade consists of a C. saccharobutylicum, C. beijerinckii subcluster, which includes C. diolis DSM 15410 and $C$. pasteurianum NRRL B-598, a C. saccharoperbutylacetonicum subclade, and a subcluster consisting of Clostridium sp. DL_VIII and BL-8. The genomes of Clostridium sp. Maddingley MBC34-24 and C. puniceum DSM 2619 branch outside the other subclades of main clade II. This result correlates with the core/pan genome analysis, as these strains, together with $C$. pasteurianum $\mathrm{BC} 1$, represent the strains with the highest number of singletons, indicating that these strains are distantly related to the other analyzed strains or species. Whilst MLSA can provide insight into the phylogenetic relationship of organisms, for taxonomic studies, other methods, such as
Average Nucleotide Identity (ANI) analysis [11], a suitable in silico alternative for DNA-DNA hybridization [12], are required. We performed an ANI analysis based on MUMmer alignment (ANIm) of the 44 genomes to define species and their complexes (Fig. 4). We identified a large $C$. beijerinckii species complex consisting of 17 strains including C. diolis DSM 15410 and C. pasteurianum NRRL B-598 having ANIm values between 96 and 100\% (Additional file 1: Table S1) compared to all other C. beijerinckii strains, which is clearly above the species threshold. The second species complex comprises all $C$. saccharobutylicum strains and our analysis demonstrates that strain L1-8 is a different subtype compared to the other strains. Our analysis also revealed that all C. acetobutylicum strains are very closely related (ANIm values of $100 \%$ ), with the exception of strain GXAS18_1 (ANIm of 98\%). In this strain, the contigs representing the sol operon are missing in the publicly available genome sequence. We identified a quite diverse species complex consisting of C. roseum DSM 7320 and DSM 6424, C. aurantibutyricum DSM 793, and C. felsineum DSM 794, but ANIm values between 98 and 100\% clearly showed that these organisms represent one species and, based on whole genome sequence comparison, these organisms have to be reclassified. Based on ANIm analysis, Clostridium sp. BL-8 and DL_VIII belong to the same species, but not to any of the described species able to perform ABE fermentation. Our analysis also showed that C. beijerinckii HUN142 and C. pasteurianum BC1 do not belong to the $C$. beijerinckii and the $C$. pasteurianum species complex, respectively and that Clostridium sp. Maddingley MBC34-24 and C. puniceum DSM 2619, respectively, have no close relative and do not belong to any of the described ABE species.

\section{Plasmids}

Plasmids have been found in 13 of the 44 analyzed ABE strains. The megaplasmid pSOL1 of $C$. acetobutylicum ATCC824 with a size of 192,000 bp is indispensable for solvent formation [14]. The strains C. acetobutylicum DSM1731, DSM1732, EA2018, and NCCB24020 carry similar megaplasmids, which also contain the sol-adc gene cluster. In addition, strain DSM1731 contains an 11,100-bp plasmid with an unknown role in clostridial physiology [15]. C. saccharoperbutylacetonicum N1-4 (HMT) contains a megaplasmid of 136,188 bp without genes apparently related to solvent formation. Strain N1-504 carries the 2936-bp plasmid pNAK1, which is identical to pCS86 from C. acetobutylicum 86 that has been used in the past for shuttle vector construction [16]. C. beijerinckii strains HUN142 and NRRL B-593 carry mostly cryptic plasmids ranging from $<2000$ to $65,000 \mathrm{bp}$. An exception is a 65,000-bp plasmid of $C$. beijerinckii 


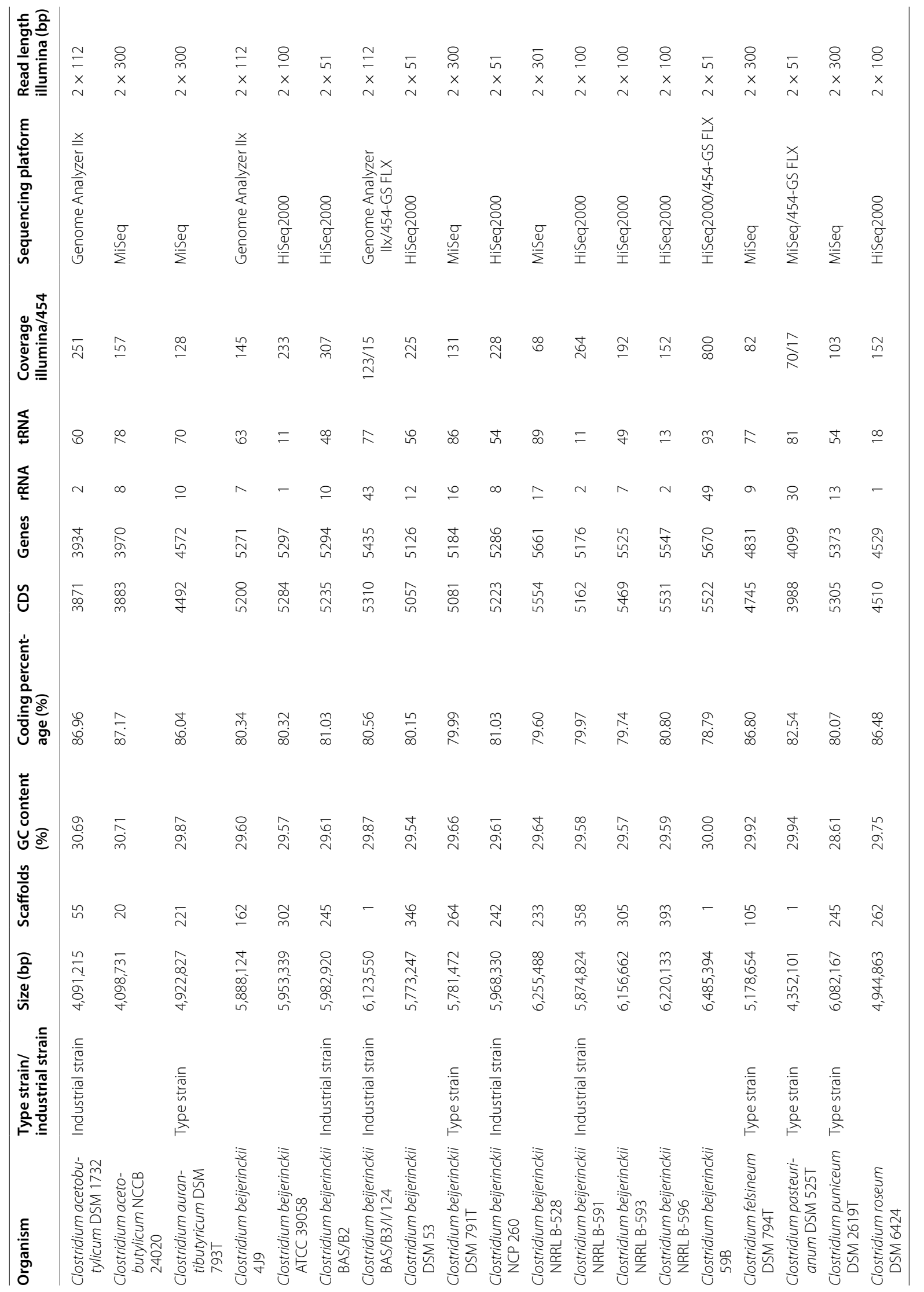




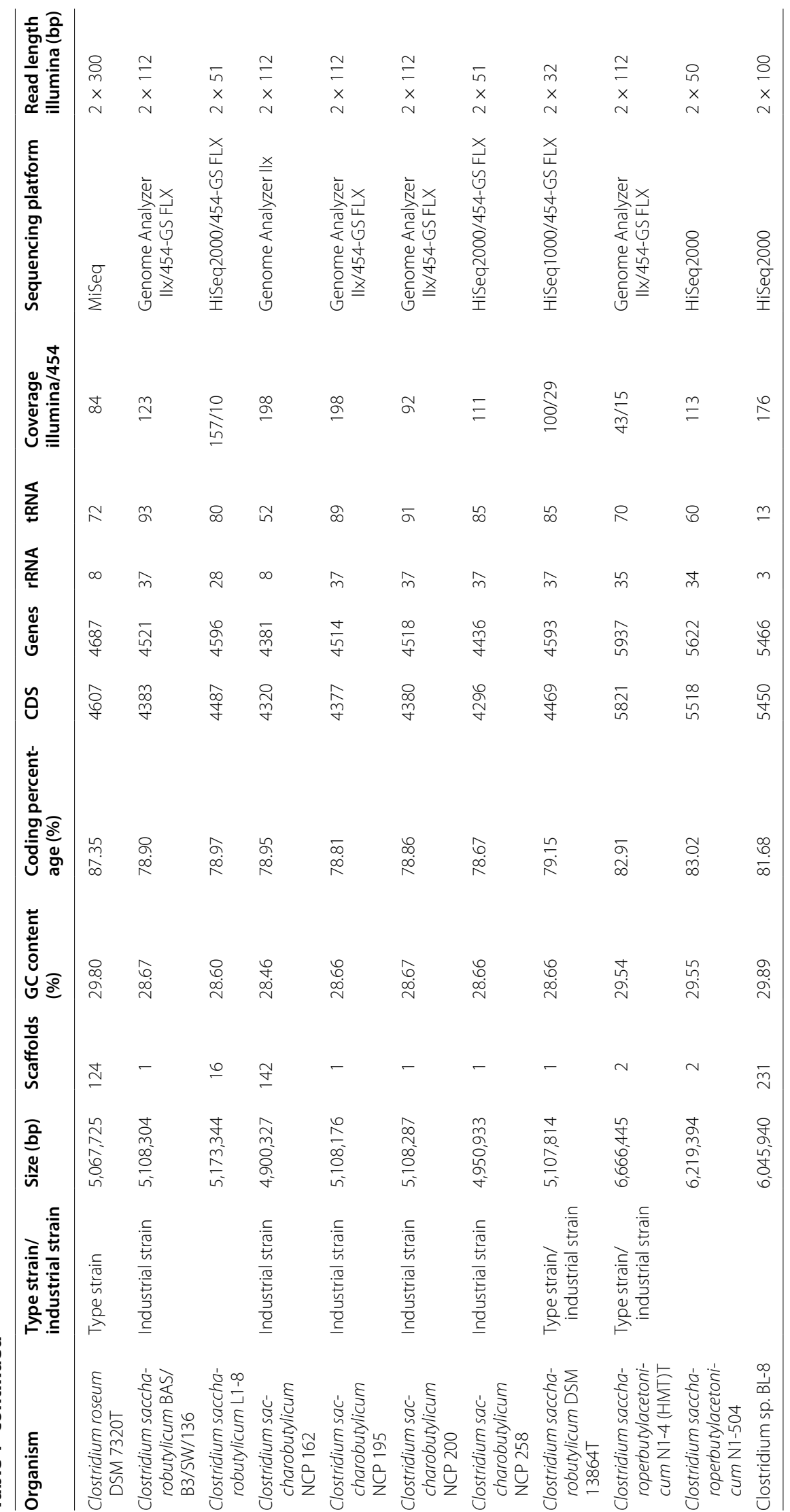




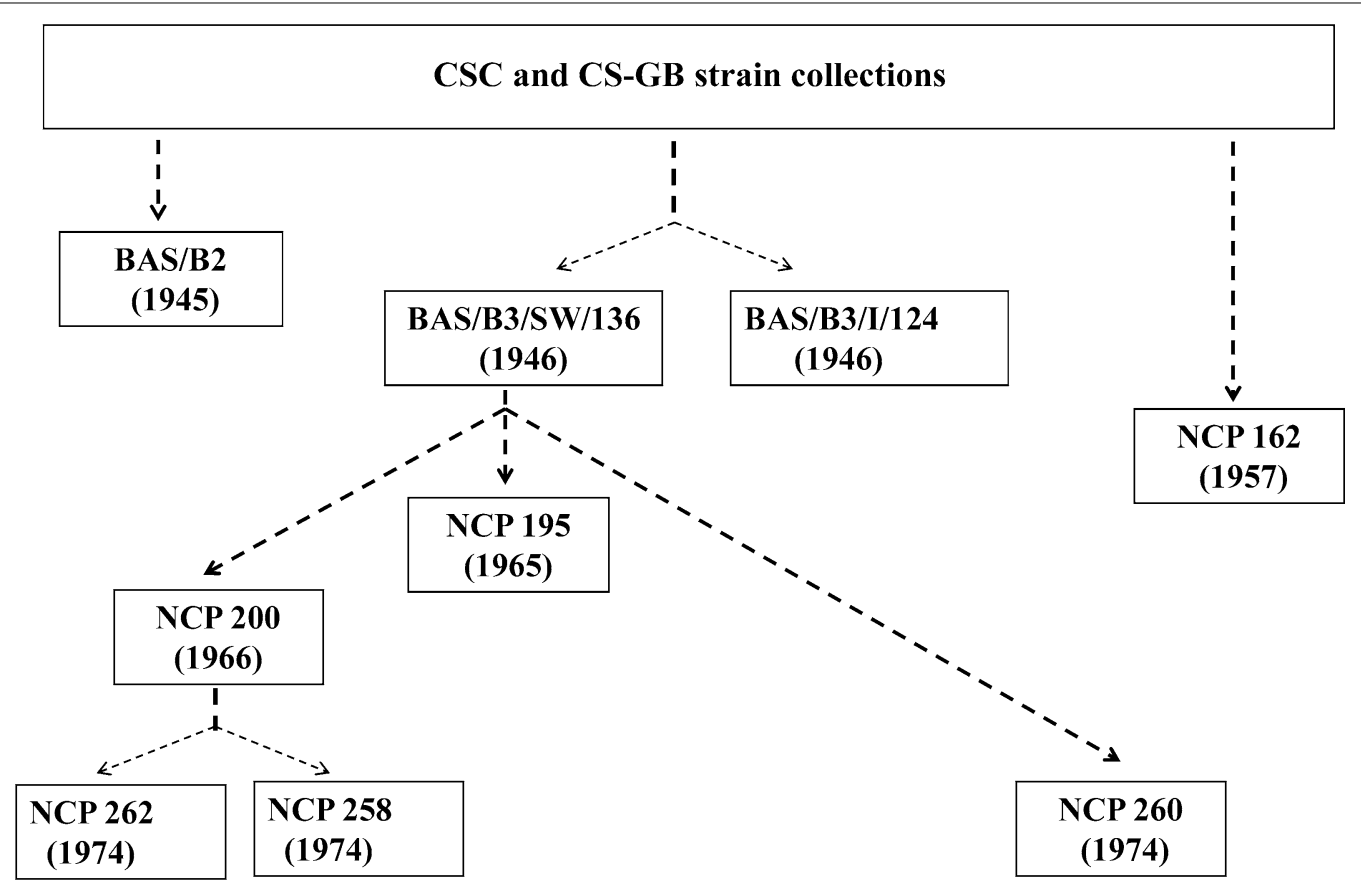

Fig. 1 Historical development of industrial ABE strains: only sequenced strains are indicated. Data stem from Jones [7]

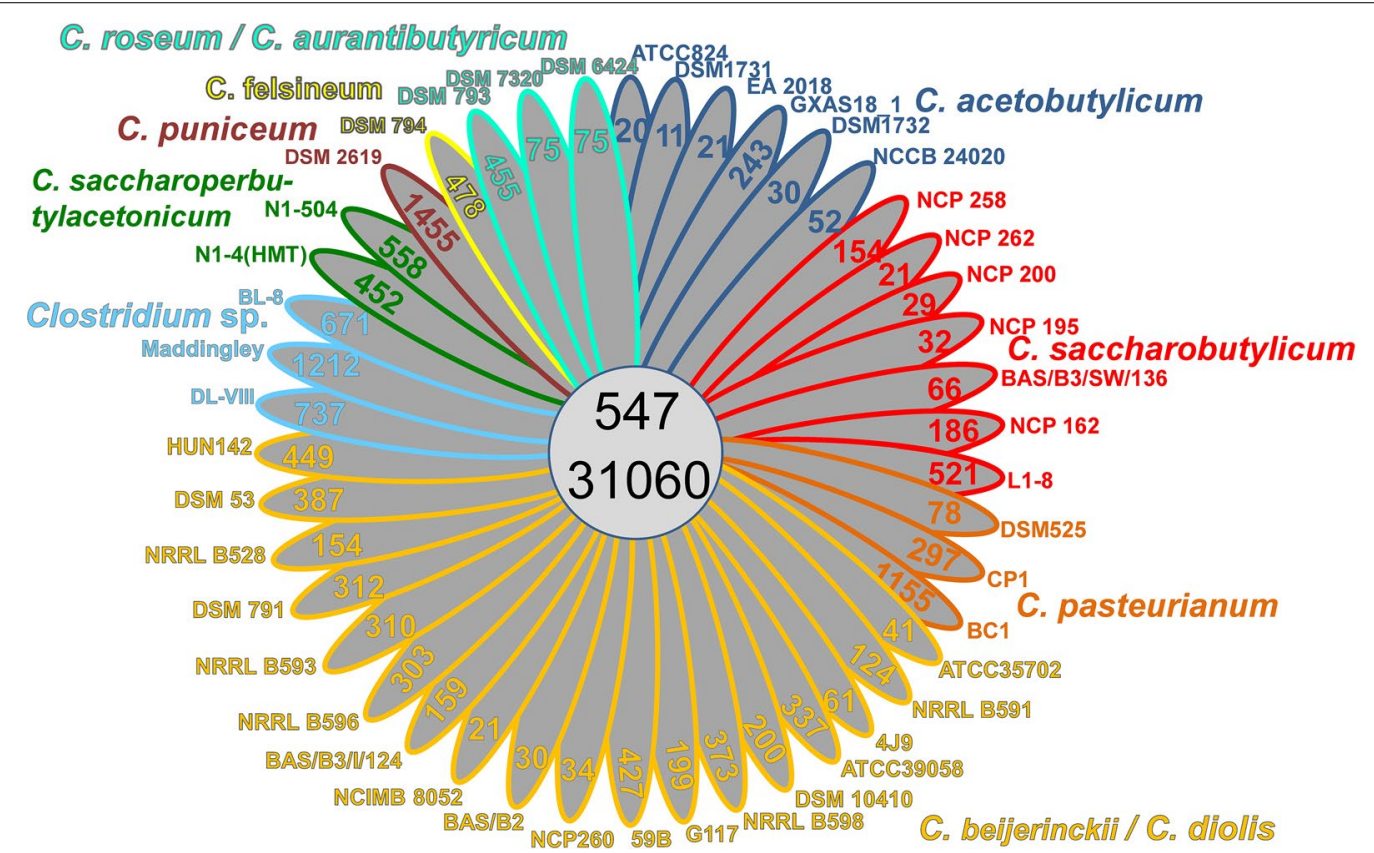

Fig. 2 Core/Pan genome analysis of 44 clostridial genomes: a simplified Venn diagram showing the core and the pan genome of all 44 solventogenic clostridia. The number of genome-specific OGs is depicted in the respective ellipse. Ortholog detection was done with blastp and the Proteinortho software [8] with a similarity cutoff of $50 \%$ and an $E$ value of $1 \mathrm{e}-10$

HUN142, which contains genes for defense (lantibiotics, proteases), antibiotic resistance, and quorum sensing. All strains of $C$. aurantibutyricum and C. roseum carry plasmids ranging from 31,015 to $55,559 \mathrm{bp}$. The misclassified C. pasteurianum $\mathrm{BC} 1$ strain also contains a plasmid with a size of 53,393 bp, and C. felsineum carries a 


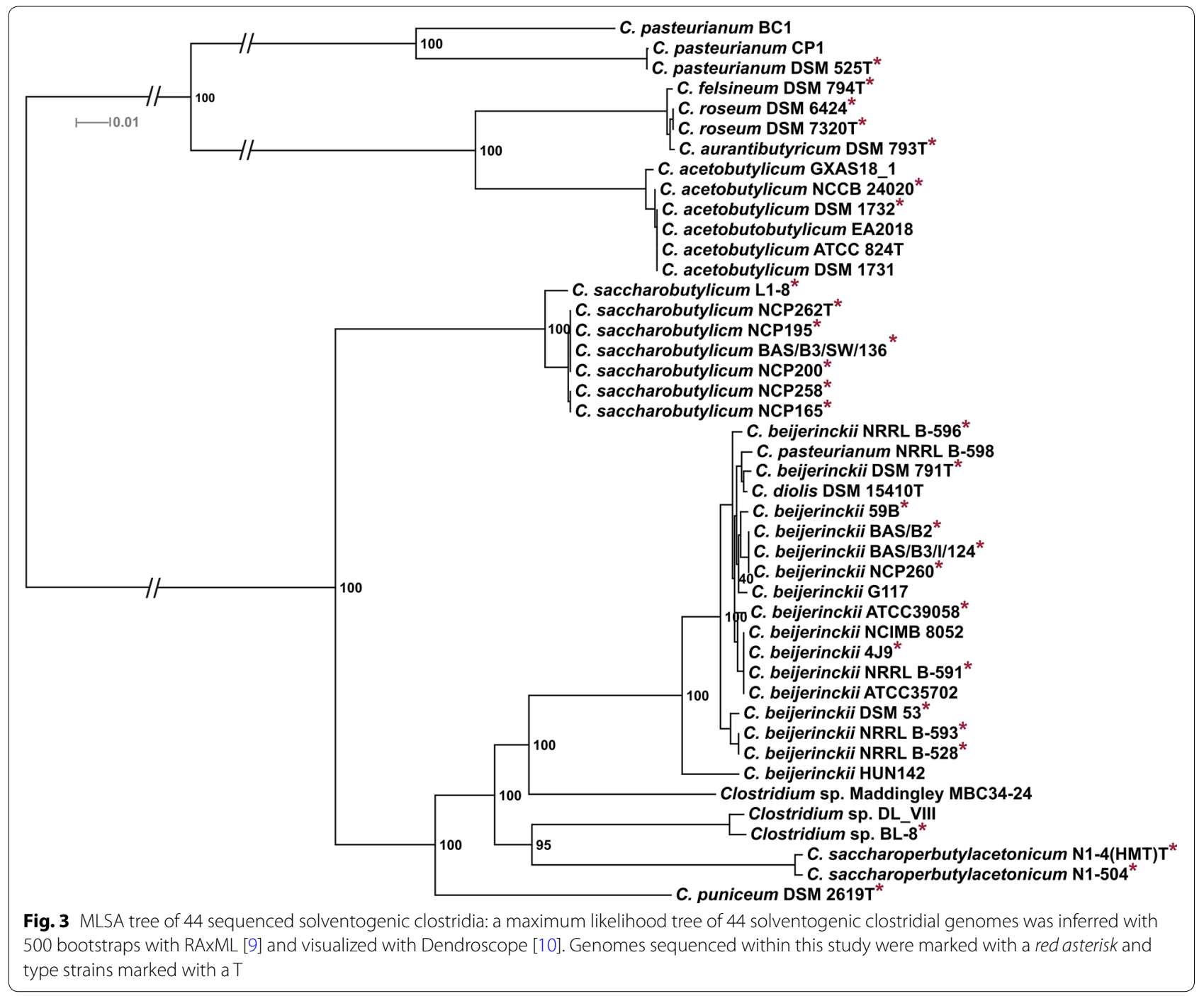

megaplasmid (339,775 bp), containing genes involved in spore germination. A detailed analysis on presence and sizes of plasmids is presented in Additional file 2: Table S2.

\section{Genes required for acidogenesis and solventogenesis}

The predominant acids formed are acetate and butyrate. Both are produced from their respective coenzyme A derivatives via transphosphorylases and kinases (Fig. 5). Genes for phosphotransacetylase and acetate kinase (pta and ack, respectively) as well as phosphotransbutyrylase and butyrate kinase ( $p t b$ and $b u k$, respectively) are organized in bi-cistronic operons in all strains analyzed. Butyrate formation starts by formation of acetoacetyl-CoA from two acetyl-CoA (catalyzed by thiolase). The following steps, conversion of acetoacetyl-CoA to butyryl-CoA, are catalyzed by enzymes whose genes are clustered in all of the strains analyzed. The order of genes in this bcs (butyryl-CoA synthesis) cluster [17] is also conserved as $c r t-b c d-e t f B-e t f A-h b d$. Analysis of putative terminators with EMBOSS and DNAsis revealed the expected terminators directly upstream of $c r t$ and downstream of $h b d$. Curiously, a hairpin structure without T-rich region was found between the genes etf $A$ and $h b d$ in all analyzed phylogenetic clusters. It may represent a former junction formed when the bcs operon was integrated during evolution or might be involved in independent regulation of the $b c s$ operon under certain growth conditions. Lactate is only formed under specific conditions [18]. All strains analyzed carry a lactate dehydrogenase gene. A previous report, comparing only the genomes of the two strains $C$. acetobutylicum ATCC 824 and C. beijerinckii NCIMB 8052, indicated the presence of a pyruvate decarboxylase gene only in $C$. 

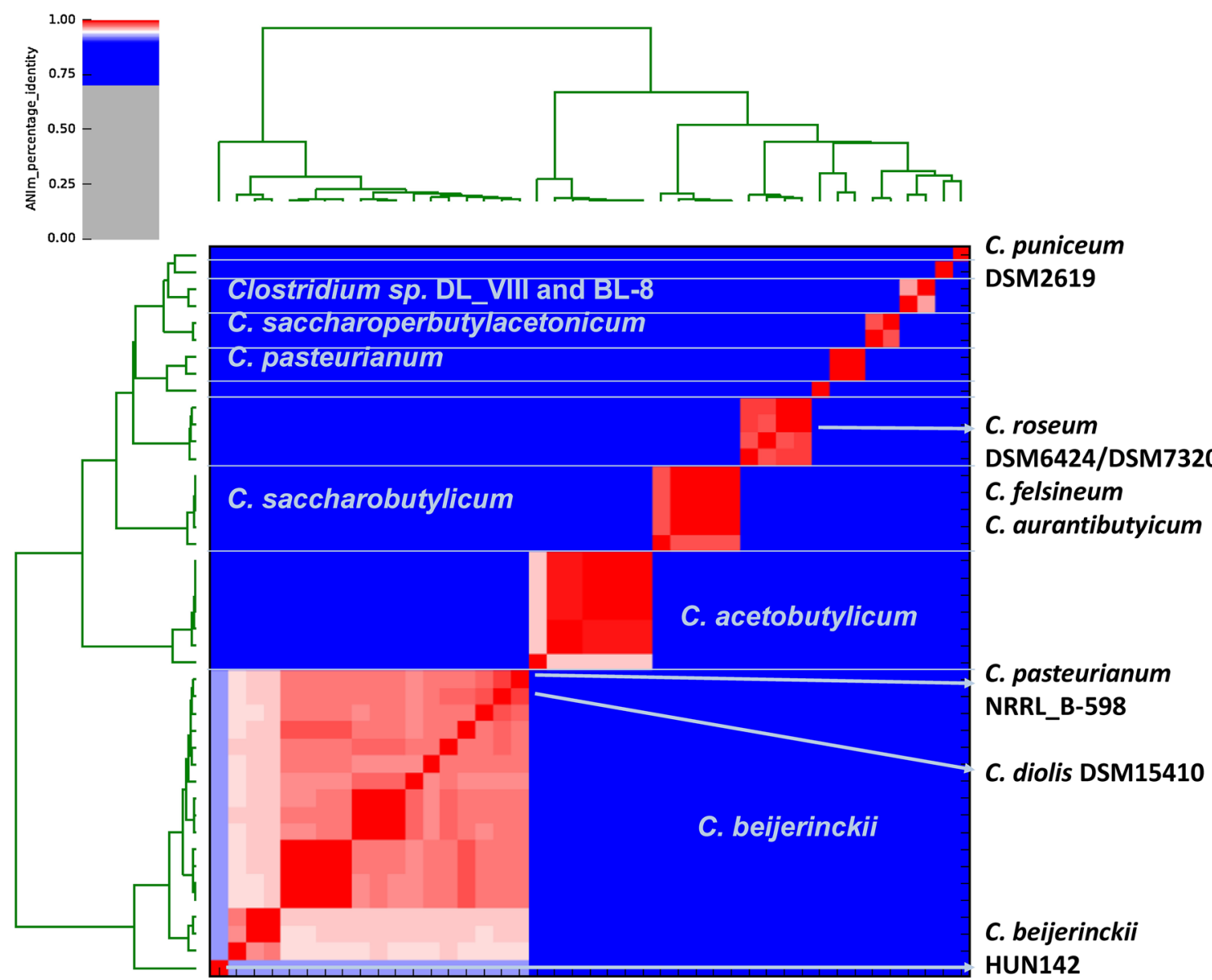

Fig. 4 Average nucleotide identity analysis of the 44 sequenced strains: ANI analysis based on MUMmer alignment of the genome sequences was performed and visualized using PYANI [13]

acetobutylicum and of genes encoding a trimeric bifurcating hydrogenase only in C. beijerinckii [19]. We could confirm that a $p d c$ gene is indeed only present in the $C$. acetobutylicum, C. aurantibutyricum/C. felsineum/C. roseum, and C. pasteurianum clade. With respect to the bifurcating hydrogenase, the result is not that unambiguous. The $C$. acetobutylicum, $C$. aurantibutyricum/C. felsineum/C. roseum, and C. pasteurianum clade lacks all three genes, but the $C$. saccharobutylicum strains and $C$. puniceum lack only one of these genes.

The organization of the genes required for solvent formation fall into two different groups, which correlate well with the two major phylogenetic groupings. Members of the clade C. acetobutylicum, C. aurantibutyricum/C. felsineum/C. roseum, and C. pasteurianum contain a sol operon, consisting of adhE-ctfA-ctfB (encoding a bifunctional butyraldehyde/butanol dehydrogenase and the two subunits of CoA transferase), and an adjacent, convergently transcribed, monocistronic adc operon (encoding acetoacetate decarboxylase) [20] (Fig. 6). In $C$. acetobutylicum strains, sol and adc operon reside on the megaplasmid pSOL1, whereas in C. aurantibutyricum/C. felsineum/C. roseum, and C. pasteurianum these genes are chromosomally located. Nevertheless, $C$. aurantibutyricum/C. felsineum/C. roseum also contain a very similar megaplasmid, but without sol and $a d c$ locus. Interestingly, sol/adc operons on the megaplasmid pSOL1 are flanked by inverted repeats, indicative of a mobile element (Fig. 7). The other clade (C. beijerinckii, C. puniceum, C. saccharobutylicum, C. saccharoperbutylacetonicum) carries a type II sol operon consisting of ald-ctfA-ctfB-adc (encoding NADH-dependent aldehyde dehydrogenase, CoA transferase, and acetoacetate decarboxylase) (Fig. 6). Detailed analyses on product formation, including references to respective experimental evidence, and gene clusters required for acidogenesis or solventogenesis, respectively, are presented in Additional file 3: Table S3 and Additional file 4: Table S4.

The availability of the industrial strain collection allowed a direct comparison of sequentially selected 


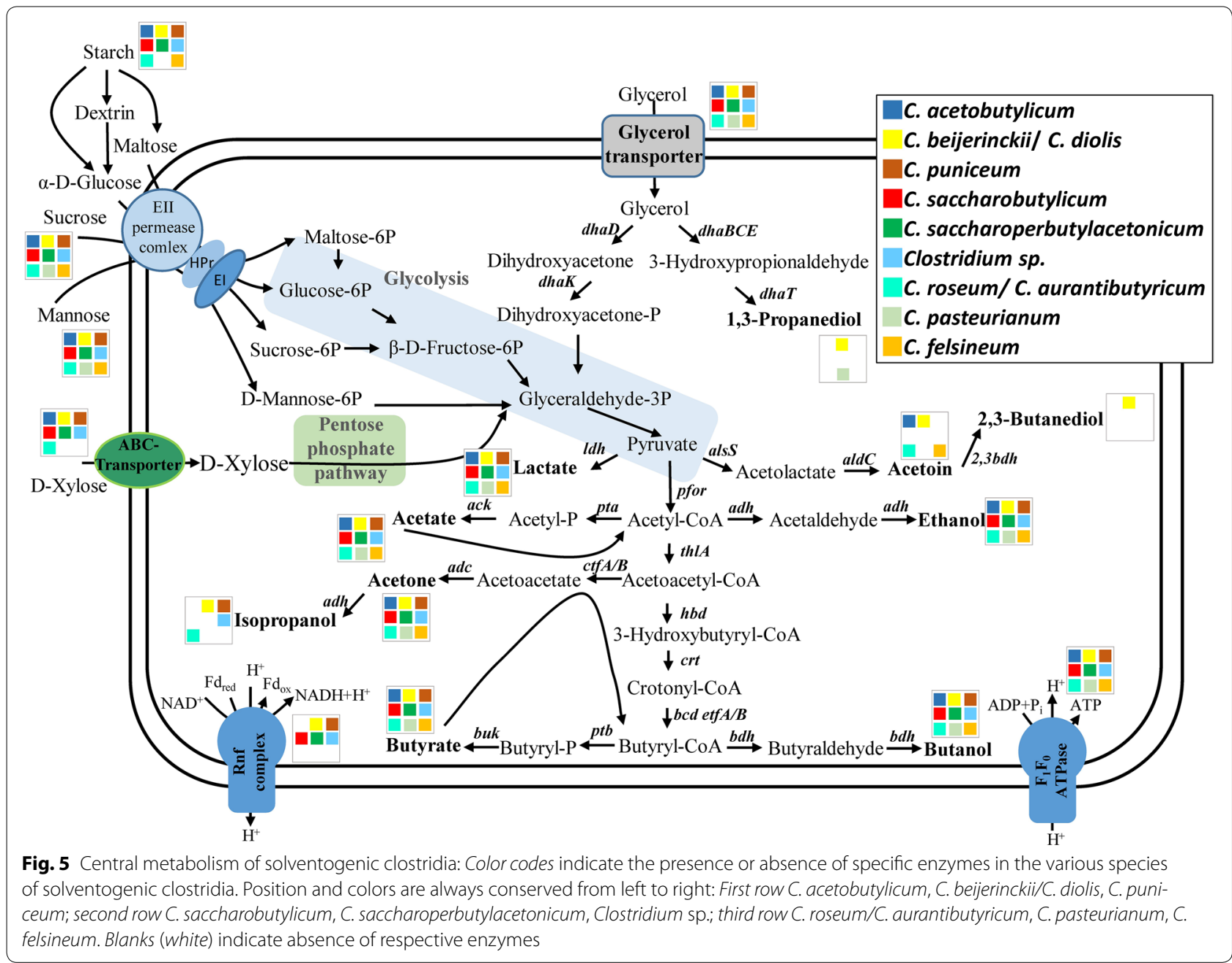

strains at the genome level. Much to our surprise, mutations in genes directly required for acidogenesis or solventogenesis were all but absent. The only example was found in C. beijerinckii NCP260, a descendant from $C$. beijerinckii BAS/B3/I/124. In NCP 260, a single-nucleotide polymorphism (SNP) was detected in the $p t b$ gene, leading to a M122I substitution. When testing the specific activity of phosphotransbutyrylase in this strain, a $54 \%$ lower activity was measured compared to the parent (Table 2). A lower capacity for butyrate production leads to higher butanol formation, a trait that is consistent with the past selection of the strain for higher butanol productivity during commercial operation.

\section{Substrate utilization}

Originally, C. acetobutylicum was isolated and grown on starch as the carbon source. Later, strains belonging to the C. beijerinckii, C. puniceum, C. saccharobutylicum, and $C$. saccharoperbutylacetonicum clade were isolated that performed better on molasses-based feedstocks.
All strains contained genes for sucrose-specific phosphotransferase systems and sucrose degradation, as well as starch degradation. The only exception with respect to starch degradation is C. pasteurianum (Fig. 5). Glycerol transporters are found in all species. Glycolysis and pentose phosphate pathway genes are always present, whereas $\mathrm{D}$-xylose $\mathrm{ABC}$ transporter genes are missing in C. felsineum and C. pasteurianum species. A detailed analysis on the presence or absence of respective genes for substrate degradation, including references to respective experimental evidence, is presented in Additional file 5: Table S5.

\section{Energy conservation}

All 44 ABE strains can synthesize ATP by substrate level phosphorylation during glycolysis (3-phosphoglycerate and pyruvate kinases), acetate (acetate kinase), and butyrate (butyrate kinase) formation, as judged from the genomic repertoire. Also, all strains have genes encoding an $\mathrm{F}_{1} \mathrm{~F}_{\mathrm{O}}$-ATPase and no genes encoding an 

C. pasteurianum
C. felsineum
C. roseum
C. aurantibutyricum
C. acetobutylicum
C. saccharobutylicum
C. beijerinckii

Clostridium sp. DL_VIII

Clostridium sp. BL-8

C. saccharoperbutylacetonicum

C. puniceum

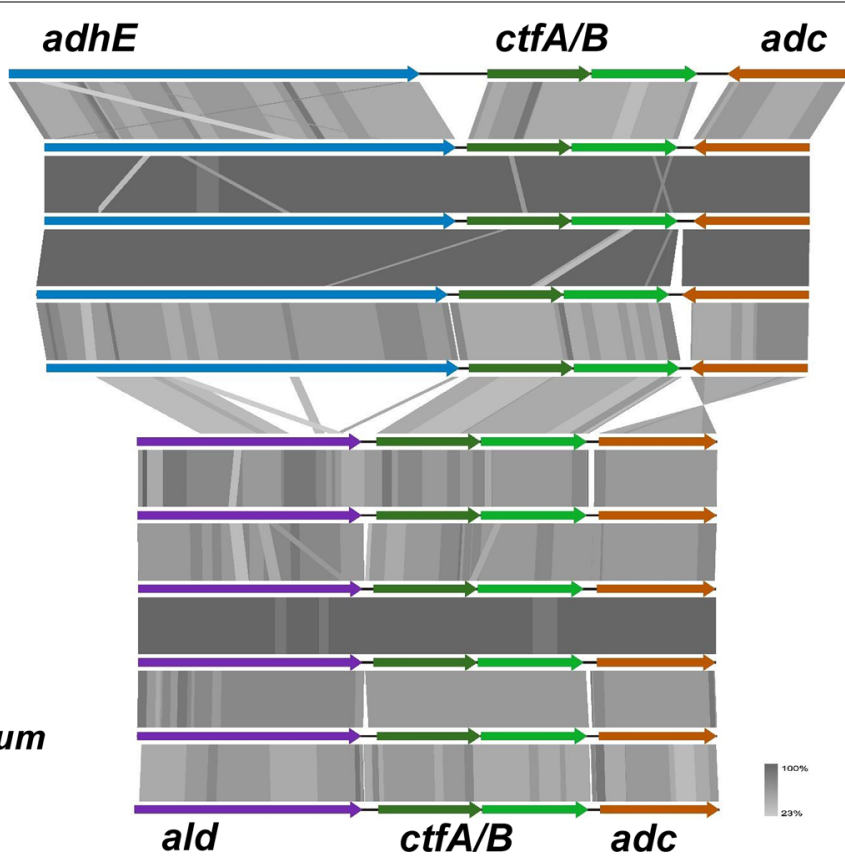

Fig. 6 Structure of the sol operon: structure of the sol operon based on Tblastx comparison of representative members of the different subclades. An $E$ value cutoff of $1 \mathrm{e}-10$ was used and visualization were done with the program Easyfig [21]

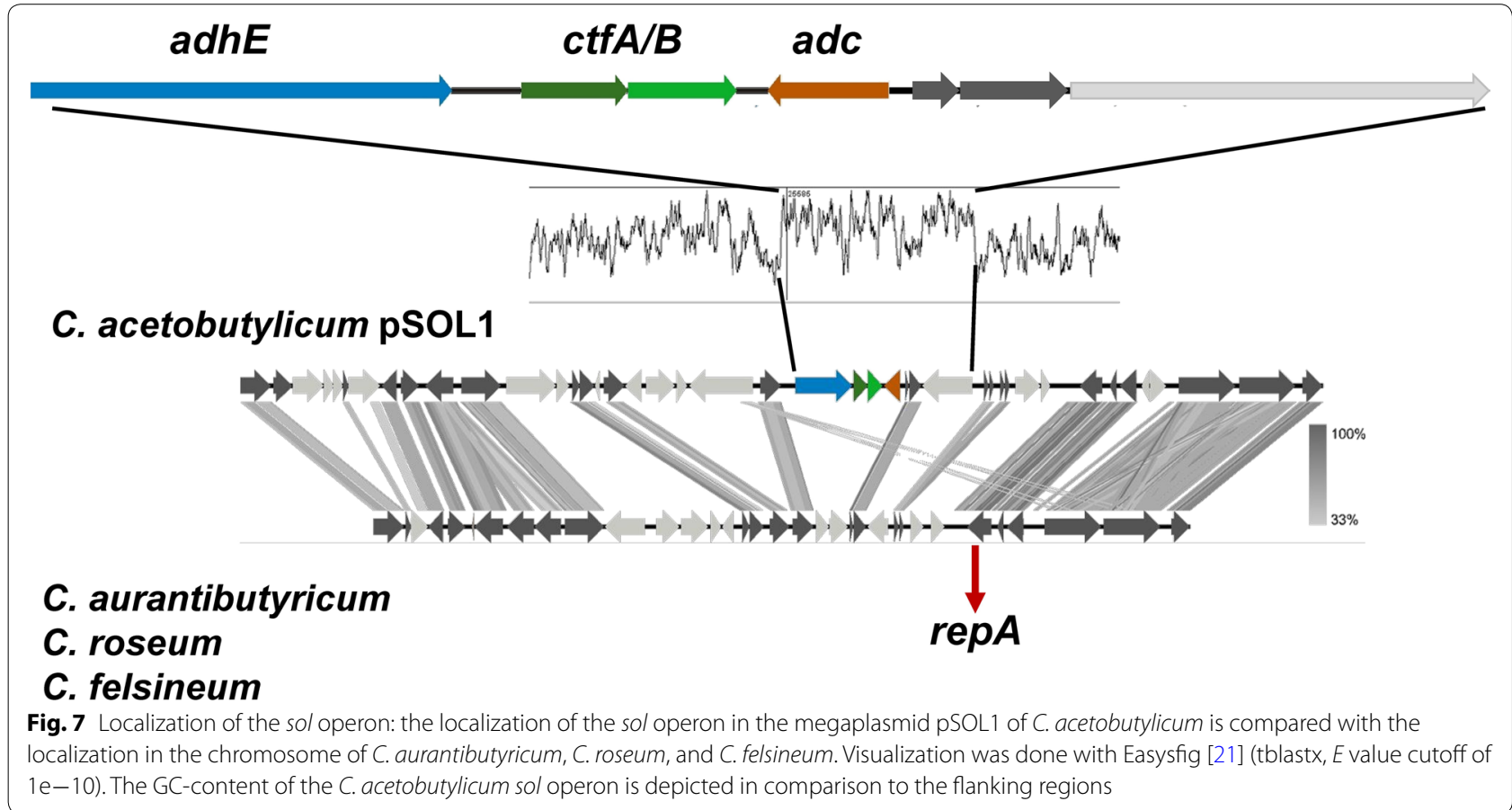

energy-conserving hydrogenase (ech). However, one major difference is found between the two phylogenetic groups: the C. beijerinckii, C. puniceum, C. saccharobutylicum, and C. saccharoperbutylacetonicum clade contains $r$ fr genes that encode a protein complex converting reduced ferredoxin to $\mathrm{NADH}$, thereby generating an ion gradient (protons or $\mathrm{Na}^{+}$) across the cytoplasmic membrane. This ion gradient can be used for additional 
Table 2 Specific phosphotransbutyrylase activity of different $C$. beijerinckii strains

\begin{tabular}{lll}
\hline Strain & \multicolumn{2}{l}{$\begin{array}{l}\text { Specific PTB activity }\left(\mathbf{U} \mathbf{~ m g}^{-\mathbf{1}}\right. \\
\text { total protein) }\end{array}$} \\
\cline { 2 - 3 } & 8-h growth & $\begin{array}{l}\text { 27-h } \\
\text { growth }\end{array}$ \\
\hline C. beijerinckii NCIMB 8052 & $58.2 \pm 2.2$ & $67.3 \pm 1.2$ \\
C. beijerinckii BAS/B3/I/124 & $80.6 \pm 4.7$ & $69.1 \pm 5.2$ \\
C. beijerinckii NCP 260 & $37.1 \pm 0.8$ & $29.7 \pm 2.9$
\end{tabular}

a Values are the average of five independent measurements \pm SD

Phosphotransbutyrylase (PTB) activity was determined according to Andersch et al. [57] in CGM cultures of the late strain NCP 260 and the early strain BAS/ B3/I/124. The strain NCIMB 8052 was used as a reference

ATP synthesis via the ATPase. No members of the $C$. acetobutylicum, C. aurantibutyricum/C. felsineum/C. roseum, and C. pasteurianum clade possess rnf genes.

\section{Regulators}

The presence of several global regulators was checked in all 44 solvent-producing strains. Spo0A is the master regulator of sporulation and also controls the onset of solventogenesis [22, 23], CodY is a pleiotropic regulator involved in degradation of macromolecules, nutrient transport, amino acid and nitrogen metabolism, chemotaxis, solventogenesis, sporulation, and synthesis of antibiotics and branched chain amino acids [24-26]; CcpA is essential for catabolite repression; and Rex controls multiple genes affecting the redox status of the cells [27-30].

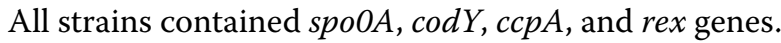

\section{Sporulation proteins and sigma factors}

Similar to Bacillus, the sporulation process in Clostridium is controlled by the orchestrated expression of a series of alternative sigma factors [22, 31, 32]. Homologs of $\operatorname{sigH}, \operatorname{sig} F, \operatorname{sig} E, \operatorname{sig} G$, and $\operatorname{sig} K$ were found in all analyzed strains. The repressor AbrB is involved in the sporulation process. Homologs of $a b r B$ were identified in all analyzed strains. An analysis on the presence or absence of respective genes for sporulation and sigma factors is presented in Additional file 6: Table S6.

\section{Quorum sensing}

The solvent-producing Clostridium species contain multiple peptide-based cell-cell signaling systems homologous to the well-studied agr and RNPP-type quorum sensing systems first identified in Staphylococcus aureus [33] and Bacillus spp. [34], respectively. The C. saccharoperbutylacetonicum genomes revealed the presence of five RNPP-type systems in addition to four putative $a g r$ systems, whereas C. acetobutylicum strains were found to only contain a single $a g r$ locus and eight RNPP-type systems [35]. The different strains of C. beijerinckii and $C$. saccharobutylicum contained up to six and three agr systems, respectively, but no complete RNPP-type systems. Thus, while physiologically similar and, in some cases, very closely related, these species have evolved rather differently in terms of their ability to communicate.

\section{Discussion}

Since the discovery of biological butanol formation in "Vibrion butyrique" (probably a mixed culture) by Louis Pasteur in 1862 [36], numerous anaerobic microorganisms showing the same metabolic property had been isolated and given a multiplicity of different names [5]. Taxonomic principles were applied much later, leading to valid descriptions in 1926 of C. acetobutylicum [3] and C. beijerinckii [37]. However, even strain deposits in acknowledged culture collections were sometimes spore-contaminated and misclassified, i.e. "C. acetobutylicum NCIMB 8052" [38], which was later shown to be a $C$. beijerinckii strain $[39,40]$. The designations $C$. saccharobutylicum and C. saccharoperbutylacetonicum were introduced with valid descriptions only in 2001 [40]. Here, we present a detailed overview of the ABEproducing clostridia, which clearly fall into two distinct phylogenetic clades. One is formed by C. acetobutylicum, C. aurantibutyricum/C. felsineum/C. roseum, and C. pasteurianum. ANIm comparisons show that the differences between C. aurantibutyricum/C. felsineum/C. roseum are only marginal and do not justify separate species designations. Amended descriptions and a common species name will be required. Conversely, C. pasteurianum $\mathrm{BC} 1$ does constitute a new species outside of C. pasteurianum. The phylogenetic grouping of the $C$. acetobutylicum, C. aurantibutyricum/C. felsineum/C. roseum, $C$. pasteurianum clade is characterized by (1) the common type I sol operon organization (gene order $a d h E-c t f A-$ $c t f B)$ and a separate $a d c$ operon, located adjacent and being transcribed convergently, (2) the absence of $r n f$ genes, thus not allowing the generation of an additional ion gradient from reduced ferredoxin, and (3) the presence of a $p d c$ gene, encoding pyruvate decarboxylase.

The second clade consists of the most widely used industrial strains (after the switch to invert sugars and molasses as substrate) and includes C. beijerinckii, $C$. saccharobutylicum, C. saccharoperbutylacetonicum, and C. puniceum. Other members are Clostridium sp. Maddingley MBC34-24 and the two Clostridium species DL VIII and BL-8, which constitute separate species and will require new descriptions and designations. Misclassified members are C. pasteurianum NRRL B-598 and C. diolis, which are clearly C. beijerinckii species. Also, C. beijerinckii HUN142 does not belong to the C. beijerinckii group and constitutes a separate species. All members 
of this second clade possess $r n f$ genes and a type II sol operon in the gene order ald $-c t f A-c t f B-a d c$ and they all miss a $p d c$ gene.

Solvent formation is mostly restricted to clostridia. Few other bacteria outside of this genus have been reported to be able to produce butanol. However, genome sequences of Eubacterium limosum SA11 [41] as well as KIST612 [42] and Butyribacterium methylotrophicum [43] reveal that such microorganisms do not possess sol operons of either clostridial type. Instead, aldehyde and alcohol dehydrogenase genes are found, whose encoded enzymes catalyze the production of butanol from butyryl-CoA. Within the archaea, only Hyperthermus butylicus has been described as a butanol producer [44, 45]. However, this is obviously an experimental flaw as genome sequencing did not reveal respective genes [46] and growth experiments on a variety of substrates never resulted in butanol formation [47]. The presence of a sol operon allows cells to couple butyrate conversion and butanol formation and thus to increase unfavorably low $\mathrm{pH}$ values to more neutral ones. This mechanism provides an ecological advantage over nutrient competitors (who would die at low $\mathrm{pH}$ ) allowing sufficient time for spore formation and thus long-time survival. As clostridia are endospore formers, this might be the reason for the evolutionary development of sol operons.

It is not obvious why $C$. acetobutylicum, $C$. aurantibutyricum/C. felsineum/C. roseum, and C. pasteurianum clade members contain a pyruvate decarboxylase (Pdc) but lack an Rnf complex. One possibility involves cofactor recycling. The $p d c$ gene in C. acetobutylicum is expressed significantly higher during acidogenesis [48]. In contrast to acetone and butanol, ethanol is already formed during the acidogenic stage. Pyruvate is first decarboxylated to acetaldehyde and $\mathrm{CO}_{2}$ (by Pdc), and the acetaldehyde is reduced to ethanol (by an alcohol dehydrogenase), requiring only $1 \mathrm{NADH}$. Conversely, ethanol formation from pyruvate via acetyl-CoA (product of the pyruvate:ferredoxin-oxidoreductase reaction) and acetaldehyde requires $2 \mathrm{NADH}$. The Rnf complex will produce additional NADH from oxidation of reduced ferredoxin. Thus, it seems that members of the C. acetobutylicum, C. aurantibutyricum/C. felsineum/C. roseum, and $C$. pasteurianum clade cannot reoxidize NADH as easily as the C. beijerinckii, C. puniceum, C. saccharobutylicum, C. saccharoperbutylacetonicum clade members and therefore possess a pyruvate decarboxylase and lack an Rnf complex.

Despite the presence of cellobiase- and cellulaseencoding genes, no solventogenic Clostridium has ever been reported to utilize cellulose. The genes encoding the putative cellulosome of $C$. acetobutylicum are exclusively transcribed throughout solventogenic growth [48]. Are they translated? If so, what is the function of the proteins during solventogenesis (the medium did not contain cellulose)? These are questions that cannot be answered by a comparative genome analysis and therefore still await experimental elucidation.

The industrial strains within the first clade that were used for the commercial production of solvents from corn are C. acetobutylicum DSM1732, EA2018, ATCC 824 and DSM 1731. The industrial strains used for commercial solvent production from molasses include $C$. beijerinckii NCIMB 8052, 4J9, NRRLB-591, and ATCC 35702. A later group of industrial strains successfully used for the commercial production of solvents from molasses are represented by C. beijerinckii BAS/B2, BAS/B/1/124, and NCP260. In addition, all of the strains belonging to the C. saccharobutylicum cluster and the C. saccharoperbutylacetonicum cluster were derived from industrial strains used for solvent production from molasses. With one exception, no key genetic features or characteristics can be identified that would have made these two major groups of successful industrial strains stand out, compared with the other non-industrial strains included in this survey. Only one mutation was identified in genes directly involved in either acid or solvent production (i.e. the $p t b$ gene) in all the industrial strains sequenced despite continuous commercial selection for improved solvent production over several decades. However, a similar phenomenon was reported with Corynebacterium glutamicum, in which improvement of amino acid production was achieved by mutations unrelated to direct amino acid metabolism $[49,50]$. This clearly indicates that bacteria evolved a complex network of metabolic reactions, which influence each other to rebalance concentrations of fermentation products. Instead of focusing on increasing expression of genes for solventogenesis and decreasing expression of genes for acidogenesis, a random mutagenesis approach might be suitable, using, e.g. the newly developed, inducible, mariner-based transposon for C. acetobutylicum [51]. In addition, the plethora of genes, stemming from this genome sequencing project, will also allow gene shuffling approaches, leading to more active enzymes.

\section{Conclusions}

Although the ABE fermentation is an established industrial process and the products are both renewable and valuable with respect to the size of both the chemical and biofuel markets (butanol is a superior biofuel to ethanol), the fermentation process has constantly struggled to compete with petrochemical synthesis with respect to feedstock cost and ultimately product pricing. Robust and highly productive strains are required for fermentation at industrial scale, using low-cost feedstocks that do 
not compete with food. The availability of a multitude of genome sequences from solvent-forming clostridia now supports detailed data mining for less obvious gene mutations and new engineering targets for improved solvent production (e.g. by gene shuffling) with the aim of developing more robust and sustainable fermentation routes for the production of acetone and butanol for chemical and biofuel applications.

\section{Methods}

\section{Bacterial strains and growth conditions}

The strains C. beijerinckii BAS/B3/I/124, NCIMB 8052, and NCP260 were maintained as spore suspensions in a modified MS mineral medium [52] and stored at $-20^{\circ} \mathrm{C}$. The medium was composed of a basal medium $\left(\mathrm{CaCO}_{3}\right.$ $11.35 \mathrm{mM}, \mathrm{KH}_{2} \mathrm{PO}_{4} 8.35 \mathrm{mM}, \mathrm{K}_{2} \mathrm{HPO}_{4} 6.52 \mathrm{mM}$, $\mathrm{MgSO}_{4} \times 7 \mathrm{H}_{2} \mathrm{O} 0.46 \mathrm{mM},\left(\mathrm{NH}_{4}\right)_{2} \mathrm{SO}_{4} 19.9 \mathrm{mM}$, Resazurin $4 \mu \mathrm{M})$, a mineral-vitamin solution $(\mathrm{NaCl} 171 \mu \mathrm{M}$, $\mathrm{Na}_{2} \mathrm{MoO}_{4} \times 2 \mathrm{H}_{2} \mathrm{O} 41.3 \mu \mathrm{M}, \mathrm{CaCl} \times 2 \mathrm{H}_{2} \mathrm{O} 68 \mu \mathrm{M}$, $\mathrm{MnSO}_{4} \times \mathrm{H}_{2} \mathrm{O} 88.7 \mu \mathrm{M}, \mathrm{FeSO}_{4} \times 7 \mathrm{H}_{2} \mathrm{O} 54 \mu \mathrm{M}$, Thiamin- $\mathrm{HCl} 5.9 \mu \mathrm{M}, p$-aminobenzoic acid $14.5 \mu \mathrm{M}$, Biotin $0.4 \mu \mathrm{M})$, and a butyrate solution $(0.1 \mathrm{M}) .1 \mathrm{ml}$ of the mineral-vitamin solution and $1 \mathrm{ml}$ of the butyrate solution were added to $10 \mathrm{ml}$ glucose $\left(20 \mathrm{~g} \mathrm{l}^{-1}\right)$ from which $600 \mu \mathrm{l}$ was mixed to $4.4 \mathrm{ml}$ basal medium. To inoculate cultures, spores were used (pasteurization for $10 \mathrm{~min}$ at $80{ }^{\circ} \mathrm{C}$ prior cultivation). All other strains were grown in CGM (Clostridium growth medium) [53], consisting of $50 \mathrm{~g}$ D-glucose $\times \mathrm{H}_{2} \mathrm{O}, 1 \mathrm{~g} \mathrm{NaCl}, 5 \mathrm{~g}$ yeast extract, $0.75 \mathrm{~g} \mathrm{KH}_{2} \mathrm{PO}_{4}, 0.75 \mathrm{~g} \mathrm{~K}_{2} \mathrm{HPO}_{4}, 0.71 \mathrm{~g} \mathrm{MgSO}_{4} \times 7 \mathrm{H}_{2} \mathrm{O}$, $2 \mathrm{~g}\left(\mathrm{NH}_{4}\right)_{2} \mathrm{SO}_{4}, 2.25 \mathrm{~g}$ asparagine $\times \mathrm{H}_{2} \mathrm{O}, 0.01 \mathrm{~g}$ $\mathrm{MnSO}_{4} \times \mathrm{H}_{2} \mathrm{O}, 0.01 \mathrm{~g} \mathrm{FeSO}_{4} \times 7 \mathrm{H}_{2} \mathrm{O}$, and $1 \mathrm{mg}$ resazurin per 1 distilled, anaerobic water. After preparation, the $\mathrm{pH}$ of CGM was 6.9. For enzyme assays, cells were grown anaerobically without agitation at $32{ }^{\circ} \mathrm{C}$ in $50 \mathrm{ml}$ CGM under anaerobic conditions at $32{ }^{\circ} \mathrm{C}$ without agitation.

\section{Genome sequencing and analysis}

Chromosomal DNA was used to prepare shotgun libraries according to the manufacturer's protocol which were subsequently sequenced (for details see Table 1). Obtained reads were processed and assembled as described in Bengelsdorf et al. [54] (for results see Table 1).

Automatic annotation was performed using the Prokka annotation pipeline [55] and additional analyses were done with the IMG/ER database [56].

Protein sequences from all genomes including the 14 publicly available ones were extracted using cds extractor.pl v0.6 (https://github.com/aleimba/bacgenomics-scripts) and used for downstream analysis with an in house pipeline (https://github.com/jvollme/
PO_2_MLSA) as described in Billerbeck et al. [9]. To calculate the average nucleotide identity of the different genomes, PYANI and the ANIm option was used (https://github.com/widdowquinn/pyani).

\section{Preparation of cell-free extract and enzyme assays}

The C. beijerinckii strains BAS/B3/I/124, NCIMB 8052, and NCP260 were grown as described above. Cells were harvested anaerobically after 8 and 27 h by centrifugation at $3214 \mathrm{~g}$ for $10 \mathrm{~min}$ at $4{ }^{\circ} \mathrm{C}$, washed twice with $20 \mathrm{ml}$ $0.1 \mathrm{M}$ potassium phosphate buffer $\mathrm{pH} 7.2$ and were stored at $-20^{\circ} \mathrm{C}$. Cell pellet was suspended in $1 \mathrm{ml} 0.1 \mathrm{M}$ potassium phosphate buffer $\mathrm{pH} 7.2$ and cooled to $0{ }^{\circ} \mathrm{C}$ on ice. This mixture was anaerobically transferred to a $2-\mathrm{ml}$ microtube with screw cap containing $0.1-\mathrm{mm}$ glass beads and then cells were disrupted in a RiboLyser ${ }^{\mathrm{TM}}$ [Hybaid Ltd., Middlesex (UK)] in five cycles at $6.5 \mathrm{~m} \mathrm{~s}^{-1}$ for $45 \mathrm{~s}$, with breaks of 2 min, during which the extracts were kept on ice. Centrifugation was performed at $38,000 \mathrm{~g}$ for $30 \mathrm{~min}$ at $4{ }^{\circ} \mathrm{C}$. Phosphotransbutyrylase (PTB) activity was assayed anaerobically at $37^{\circ} \mathrm{C}$. The enzyme PTB catalyzes the reaction of butyryl-CoA and phosphate to butyryl-phosphate and CoA. The sulfuryl group of the latter was quantified by the absorbance at $405 \mathrm{~nm}$ in the presence of DTNB [5,5'-dithiobis-(2-nitrobenzoic acid)]. The activity of PTB in crude extract was measured by monitoring the formation of the reaction product at $405 \mathrm{~nm}$. For activity calculation, the extinction coefficient of $13.6 \mathrm{mM}^{-1} \mathrm{~cm}^{-1}$ was used. One unit of PTB is defined as the amount of the enzyme that produces $1 \mu \mathrm{mol}$ of butyryl-CoA per minute under the reaction conditions. The total protein concentration was measured using Pierce BCA Protein Assay Kit (Thermo Scientific). Specific PTB activity was expressed as units $\left(\mu \mathrm{mol} \mathrm{min}{ }^{-1}\right)$ per milligram of protein [U (mg of total protein $\left.)^{-1}\right]$. PTB activity was determined as described by Andersch et al. [57].

\section{Accession numbers}

These Whole Genome Shotgun projects have been deposited at DDBJ/ENA/GenBank. For details, see Additional file 7: Table S7.

\section{Additional files}

Additional file 1: Table S1. ANIm values calculated with PYANI.

Additional file 2: Table S2. Plasmids.

Additional file 3: Table S3. Products (acids and solvents). Additional file 4: Table S4. Acidogenensis and solventogenesis gene clusters.

Additional file 5: Table S5. Substrate degradation.

Additional file 6: Table S6. Sporulation proteins and $\sigma$-factors.

Additional file 7: Table S7. General GenBank features. 


\section{Abbreviations}

ABE: acetone-butanol-ethanol; ANI: average nucleotide identity; CGM: Clostridium growth medium; CSC: Commercial Solvents Corporation; CS-GB: Commercial Solvents-Great Britain; MSLA: multi-locus sequence analysis; NCP: National Chemical Products; OGs: orthologous groups; SNP: single-nucleotide polymorphism; WW: world war.

\section{Authors' contributions}

EG, PK, NPM, RD, and PD designed the study. AP and PK carried out the genomic and phylogenetic analyses. JDMS and SF carried out enzyme assays and AP, JDMS, SF, and KW genome comparisons. SJR and DTJ provided strains. AP and PD wrote the major parts of the manuscript and all authors contributed to writing and revising it. All authors read and approved the final manuscript.

\section{Author details \\ ${ }^{1}$ Genomic and Applied Microbiology and Göttingen Genomics Labora- tory, Georg-August University Göttingen, Grisebachstr. 8, 37077 Göttingen, Germany. ${ }^{2}$ Institut für Mikrobiologie und Biotechnologie, Universität Ulm, Albert-Einstein-Allee 11, 89081 Ulm, Germany. ${ }^{3}$ Green Biologics Ltd., 45A Western Avenue, Milton Park, Abingdon, Oxfordshire OX14 4RU, UK. ${ }^{4}$ Clostridia Research Group, BBSRC/EPSRC Synthetic Biology Research Centre (SBRC), School of Life Sciences, University of Nottingham, Nottingham NG7 2RD, UK. ${ }^{5}$ Department of Molecular and Cell Biology, University of Cape Town, Rondebosch, Cape Town 7701, South Africa. ${ }^{6}$ Department of Microbiology and Immunology, University of Otago, Dunedin 9010, New Zealand. ${ }^{7}$ CHAIN Biotechnology Ltd., Imperial College Incubator, Level 1 Bessemer Building, Imperial College London, London SW7 2AZ, UK.}

\section{Acknowledgements}

The Illumina sequencing of C. saccharoperbutylacetonicum N1-504, C. beijerinckii DSM 53, BAS/B2, NCP 260, and C. saccharobutylicum NCP 258, L1/8 was carried out by Green Biologics, while the Illumina sequencing of $C$. beijerinckil NRRL B-591, NRRL B-593, NRRL B-596, ATCC 39058, C. roseum DSM 6424, and Clostridium sp. BL-8 was carried by Green Biologics and supported via Innovate UK grant (Project No. 130860). The authors would like to acknowledge Dr. Amanda Harding and Dr. Holly Smith for generating gDNA, to thank Prof. Giorgio Mastromei for C. saccharobutylicum L1/8 and Dr. William Moe for Clostridium sp. BL-8, and Andre van der Westhuizen at NCP for C. beijerinckii BAS/B2, BAS/B3/I/124 and C. saccharobutylicum BAS/B3/SW/136, Frauke-Dorothee Meyer and Kathleen Gollnow for technical support, Andreas Leimbach for bioinformatic advice, and Annerose Frank-Barone for preparing Fig. 1.

\section{Competing interests}

The authors declare that they have no competing interests.

\section{Availability of data and materials}

All data generated or analyzed during this study are included in this published article and its supplementary information files.

\section{Funding}

This study was supported by the ERA-IB project REACTIF (Rational Engineering of Advanced Clostridia for Transformational Improvements in Fermentation), EIB 12.050 and the Innovate UK Grant (Project No. 130860).

Received: 15 October 2016 Accepted: 28 February 2017 Published online: 09 March 2017

\section{References}

1. Sutcliffe S. Green Biologics funding story. http://www.rushlightevents. com/wp-content/uploads/2014/01/R-Show-14-FCC-Sean-Sutcliffe.pdf. Accessed Jan 272017.

2. Weizmann C. Improvement in the bacterial fermentation of carbohydrates and in bacterial cultures for the same. British Patent 4845; 1915.

3. McCoy E, Fred EB, Peterson WH, Hastings EG. A cultural study of the acetone butyl alcohol organism. J Infect Dis. 1926;39:457-83.

4. Jones DT, Woods DR. Acetone-butanol fermentation revisited. Microbiol Rev. 1986:50:484-524
5. Dürre P, Bahl H. Microbial production of acetone/butanol/isopropanol. In: Rehm HJ, Reed G, editors. Biotechnology: products of primary metabolism. New York: Wiley; 1996. p. 229-68.

6. Jones DT. The strategic importance of butanol for Japan during WWII: a case study of the butanol fermentation process in Taiwan and Japan. In: Dürre P, editor. Systems biology of Clostridium. London: Imperial College Press; 2014. p. 220-72.

7. Jones DT. Applied acetone-butonal fermentation. In: Bahl H, Dürre P, editors. Clostridia: biotechnology and medical applications. New York: Wiley; 2001. p. 125-68.

8. Lechner M, Findeiss S, Steiner L, Marz M, Stadler PF, Prohaska SJ. Proteinortho: detection of (co-)orthologs in large-scale analysis. BMC Bioinform. 2011;12:124.

9. Billerbeck S, Wemheuer B, Voget S, Poehlein A, Giebel HA, BrinkhoffT, Gram L, Jeffrey WH, Daniel R, Simon M. Biogeography and environmental genomics of the Roseobacter-affiliated pelagic CHAB-I-5 lineage. Nat Microbiol. 2016;1:16063.

10. Huson DH, Richter DC, Rausch C, Dezulian T, Franz M, Rupp R. Dendroscope: an interactive viewer for large phylogenetic trees. BMC Bioinform. 2007;8:460.

11. Richter M, Rossello-Mora R. Shifting the genomic gold standard for the prokaryotic species definition. Proc Natl Acad Sci. 2009;106:19126-31.

12. Goris J, Konstantinidis KT, Klappenbach JA, Coenye T, Vandamme P, Tiedje JM. DNA-DNA hybridization values and their relationship to wholegenome sequence similarities. Int J Syst Evol Microbiol. 2007;57:81-91.

13. Online repository for pyani. https://github.com/widdowquinn/pyani. Accessed March 32016.

14. Cornillot E, Nair RV, Papoutsakis ET, Soucaille P. The genes for butanol and acetone formation in Clostridium acetobutylicum ATCC 824 reside on a large plasmid whose loss leads to degeneration of the strain. J Bacteriol. 1997;179:5442-7.

15. Bao G, Wang R, Zhu Y, Dong H, Mao S, Zhang Y, Chen Z, Li Y, Ma Y Complete genome sequence of Clostridium acetobutylicum DSM 1731, a solvent-producing strain with multireplicon genome architecture. J Bacteriol. 2011;193:5007-8.

16. Yoshino S, Yoshino T, Hara S, Ogata S, Hayashida S. Construction of shuttle vector plasmid between Clostridium acetobutylicum and Escherichia coli. Agric Biol Chem. 1990;54:437-41.

17. Boynton ZL, Bennett GN, Rudolph FB. Cloning, sequencing, and expression of genes encoding phosphotransacetylase and acetate kinase from Clostridium acetobutylicum ATCC 824. Appl Environ Microbiol. 1996;62:2758-66

18. Bahl H, Gottwald M, Kuhn A, Rale V, Andersch W, Gottschalk G. Nutritional factors affecting the ratio of solvents produced by Clostridium acetobutylicum. Appl Environ Microbiol. 1986;52:169-72.

19. Siemerink MAJ, Schwarz K, Kuit W, Kengen SWM. Comparative genomic analysis of the central metabolism of the solventogenic species Clostridium acetobutylicum ATCC 824 and Clostridium beijerinckii NCIMB 8052. In: Dürre P, editor. Systems biology of Clostridium. London: Imperial College Press; 2014. p. 193-219.

20. Gerischer U, Dürre P. Cloning, sequencing, and molecular analysis of the acetoacetate decarboxylase gene region from Clostridium acetobutylicum. J Bacteriol. 1990;172:6907-18.

21. Sullivan MJ, Petty NK, Beatson SA. Easyfig: a genome comparison visualizer. Bioinformatics. 2011;27:1009-10.

22. Harris LM, Welker NE, Papoutsakis ET. Northern, morphological, and fermentation analysis of SPO0A inactivation and overexpression in Clostridium acetobutylicum ATCC 824. J Bacteriol. 2002;184:3586-97.

23. Burbulys D, Trach KA, Hoch JA. Initiation of sporulation in B. subtilis is controlled by a multicomponent phosphorelay. Cell. 1991;64:545-52.

24. Molle V, Nakaura Y, Shivers RP, Yamaguchi H, Losick R, Fujita Y, Sonenshein AL. Additional targets of the Bacillus subtilis global regulator CodY identified by chromatin immunoprecipitation and genome-wide transcript analysis. J Bacteriol. 2003;185:1911-22.

25. Belitsky BR, Sonenshein AL. Contributions of multiple binding sites and effector-independent binding to CodY-mediated regulation in Bacillus subtilis. J Bacteriol. 2011;193:473-84.

26. Standfest T. Optimierung und alternative Substrate in der ABE-Fermentation mit Clostridium acetobutylicum. (Ph.D. thesis, Universität Ulm, 2013).

27. Ren C, Gu Y, Wu Y, Zhang W, Yang C, Yang S, Jiang W. Pleiotropic functions of catabolite control protein CcpA in butanol-producing Clostridium acetobutylicum. BMC Genom. 2012;13:349. 
28. Wietzke M, Bahl H. The redox-sensing protein Rex, a transcriptional regulator of solventogenesis in Clostridium acetobutylicum. Appl Microbiol Biotechnol. 2012;96:749-61.

29. Henkin TM, Grundy FJ, Nicholson WL, Chambliss GH. Catabolite repression of a amylase gene expression in Bacillus subtilis involves a trans-acting gene product homologous to the Escherichia coli lacl and galR repressors. Mol Microbiol. 1991;5:575-84.

30. Wang E, Bauer MC, Rogstam A, Linse S, Logan DT, von Wachenfeldt C. Structure and functional properties of the Bacillus subtilis transcriptional repressor Rex. Mol Microbiol. 2008;69:466-78.

31. Al-Hinai MA, Jones SW, Papoutsakis ET. The Clostridium sporulation programs: diversity and preservation of endospore differentiation. Microbiol Mol Biol Rev. 2015;79:19-37.

32. Paredes CJ, Alsaker KV, Papoutsakis ET. A comparative genomic view of clostridial sporulation and physiology. Nat Rev Microbiol. 2005;3:969-78.

33. Rocha-Estrada J, Aceves-Diez A, Guarneros G, De La Torre M. The RNPP family of quorum-sensing proteins in Gram-positive bacteria. Appl Microbiol Biotechnol. 2010;87:913-23.

34. Lyon GJ, Novick RP. Peptide signaling in Staphylococcus aureus and other Gram-positive bacteria. Peptides. 2004;25:1389-403.

35. Kotte AK. RNPP-type quorum sensing in Clostridium acetobutylicum. (Ph.D. thesis, University of Nottingham, 2013).

36. Pasteur $L$. Quelques résultats nouveaux relatifs aux fermentations acétique et butyrique. Bull Soc Chim Paris Mai 1862;52-53.

37. Donker HJL. Bijdrage tot de kennis der boterzuur-,buttylalcoholen acetongistingen. (Ph.D. thesis, Delft University, 1926).

38. Jones DT, Keis S. Origins and relationships of the industrial solvent-producing clostridial strains. FEMS Microbiol Lett. 1995;17:223-32.

39. Keis S, Bennett CF, Ward VK, Jones DT. Taxonomy and phylogeny of industrial solvent-producing clostridia. Int J Syst Bacteriol. 1995;45:693-705.

40. Keis S, Shaheen R, Jones DT. Emended descriptions of Clostridium acetobutylicum and Clostridium beijerinckii, and descriptions of Clostridium saccharoperbutylacetonicum sp. nov. and Clostridium saccharobutylicum sp. nov. Int J Syst Evol Microbiol. 2001;51:2095-103.

41. Kelly WJ, Henderson G, Pacheco DM, Li D, Reilly K, Naylor GE, Janssen PH, Attwood GT, Altermann E, Leahy SC. The complete genome sequence of Eubacterium limosum SA11, a metabolically versatile rumen acetogen. Stand Genomic Sci. 2016;11:26.

42. Roh H, Ko HJ, Kim D, Choi DG, Park S, Kim S, Chang IS, Choi IG. Complete genome sequence of a carbon monoxide-utilizing acetogen, Eubacterium limosum KIST612. J Bacteriol. 2011;193:307-8.

43. Bengelsdorf FR, Poehlein A, Schiel-Bengelsdorf B, Daniel R, Dürre P. Genome sequence of the acetogenic bacterium Butyribacterium methylotrophicum DSM 3468T. Genome Announc. 2016:4(6):e01338-16. doi:10.1128/genomeA.01338-16.

44. Zillig W, Holz I, Janekovic D, Klenk HP, Imsel E, Trent J, Wunderl S, Forjaz $\mathrm{VH}$, Coutinho R, Ferreira T. Hyperthermus butylicus, a hyperthermophilic sulfur-reducing archaebacterium that ferments peptides. J Bacteriol. 1990;172:3959-65.

45. Kim JW, Peeples TL. Screening extremophiles for bioconversion potentials. Biotechnol Prog. 2006;22:1720-4.

46. Brügger K, Chen L, Stark M, Zibat A, Redder P, Ruepp A, Awayez M, She Q, Garrett RA, Klenk HP. The genome of Hyperthermus butylicus: a sulfurreducing, peptide fermenting, neutrophilic crenarchaeote growing up to 108 C. Archaea. 2007;2:127-35.

47. Zimmermann T. Untersuchungen zur Butanolbildung von Hyperthermus butylicus und Clostridium acetobutylicum. (Ph.D. thesis, Universität Ulm, 2013).

48. Grimmler C, Janssen H, Krauße D, Fischer R-J, Bahl H, Dürre P, Liebl W, Ehrenreich A. Genome-wide gene expression analysis of the switch between acidogenesis and solventogenesis in continuous cultures of Clostridium acetobutylicum. J Mol Microbiol Biotechnol. 2011;20:1-15.

49. Binder S, Schendzielorz G, Stäbler N, Krumbach K, Hoffmann K, Bott M, Eggeling L. A high-throughput approach to identify genomic variants of bacterial metabolite producers at the single-cell level. Genome Biol. 2012;13:R40.

50. Bott M. Need for speed - finding productive mutations using transcription factor-based biosensors, fluorescence-activated cell sorting and recombineering. Microbial Biotechnol. 2015;8:8-10.

51. Zhang Y, Xu S, Chai C, Yang S, Jiang W, Minton NP, Gu Y. Development of an inducible transposon system for efficient random mutagenesis in Clostridium acetobutylicum. FEMS Microbiol Lett. 2016. doi:10.1093/ femsle/fnw065.

52. Monot F, Martin JR, Petididemange H, Gay R. Acetone and butonal production by Clostridium acetobutylicum in a synthetic medium. Appl Environ Microbiol. 1982:44:1318-24

53. Roos JW, McLaughlin JK, Papoutsakis ET. The effect of $\mathrm{pH}$ on nitrogen supply, cell lysis, and solvent production in fermentations of Clostridium acetobutylicum. Biotechnol Bioeng. 1985;27:681-94.

54. Bengelsdorf FR, Poehlein A, Linder S, Erz C, Hummel T, Hoffmeister S, Daniel R, Dürre P. Industrial acetogenic biocatalysts: a comparative metabolic and genomic analysis. Front Microbiol. 2016;7:1036.

55. Seemann T. Prokka: rapid prokaryotic genome annotation. Bioinformatics. 2014;30:2068-9.

56. Markowitz VM, Chen IM, Palaniappan K, Chu K, Szeto E, Pillay M, Ratner A, Huang J, Woyke T, Huntemann M, Anderson I, Billis K, Varghese N, Mavromatis K, Pati A, Ivanova NN, Kyrpides NC. IMG 4 version of the integrated microbial genomes comparative analysis system. Nucl Acids Res. 2014;42:568-73.

57. Andersch W, Bahl H, Gottschalk G. Level of enzymes involved in acetate, butyrate, acetone and butanol formation by Clostridium acetobutylicum. Eur J Appl Microbiol Biotechnol. 1983;18:327-32.

\section{Submit your next manuscript to BioMed Central and we will help you at every step:}

- We accept pre-submission inquiries

- Our selector tool helps you to find the most relevant journal

- We provide round the clock customer support

- Convenient online submission

- Thorough peer review

- Inclusion in PubMed and all major indexing services

- Maximum visibility for your research

Submit your manuscript at www.biomedcentral.com/submit 